ISSN (print): 0853-8301; ISSN (online): 2745-777X

Available online at https://ejournal.unib.ac.id/index.php/triadik

DOI: https://doi.org/10.33369/triadik.v19i2.16456

page: $18-25$

\title{
STUDI DESKTIPRIF TINGKAT SUBJETIVE WELL BEING SISWA SMA NEGERI DAN SWASTA DI KOTA BENGKULU
}

\author{
${ }^{1}$ Medi Anugra, 2 I Wayan Dharmayana, ${ }^{3}$ Afifatus Sholihah
}

\author{
Universitas Bengkulu
}

Korespondensi: anugramedi07@gmail.com

\begin{abstract}
Abstrak
Tujuan penelitian ini adalah untuk mengetahui tingkat subjective well being siswa SMA Negeri dan swasta di Kota Bengkulu. Penelitian ini termasuk dalam deskriptif kuantitatif. Teknik penelitian stratified cluster sampling dan menggunakan angket dengan 52 item pernyataan. Sampel Penelitian ini SMA Negeri 5 sebanyak 160 Responden, SMA Negeri 10 sebanyak 154 Responden, SMA Muhamdiyah sebanyak 133 Responden, dan SMA It Iqra sebanyak 152 Responden. Metode analisis data menggunakan rumus persentase melalui rumus skala Likert. Hasil penelitian pada SMA Negeri 5 Kota Bengkulu di peroleh nilai 21.0\% pada tingkat tinggi. Hasil penelitian pada SMA Negeri 10 Kota Bengkulu di peroleh nilai $21.0 \%$ pada tingkat tinggi. Hasil penelitian pada SMA Muhamadiya 4 di peroleh nilai $14.9 \%$ pada tingkat rendah.. Selanjutnya Hasil penelitian pada SMA IT Iqra di peroleh nilai $19.9 \%$ pada tingkat rendah.
\end{abstract}

Kata kunci: Subjective Well Being, sekolah swasta, sekolah negeri

\begin{abstract}
The purpose of this study description the level of subjetive well being of state high school dan private high school students at kota bengkulu. The research technique stratified cluster sampling and used questionnaires within 52 statement items. This research sampel SMA Negeri 5 kota Bengkulu as 160 respondent, This research sampel SMA Negeri 10 kota Bengkulu as 154 respondent, This research sampel SMA Muhamdiyah as 133 respondent, and this research sampel SMA IT Iqra as 152 respondent, Data analysis method used the formula of Likert scales. The research results at SMA Negeri 5 kota Bengkulu earned value $21.0 \%$ in the high category, The research results at SMA Negeri 10 kota Bengkulu earned value $21.0 \%$ in the high category, The research results at SMA Muhamdiyah earned value $14.9 \%$ in the is on category, and the research results at SMA It Iqra earned value $19.9 \%$ in the is on category.
\end{abstract}

Keywords: Subjective Well Being, private school, public school

\section{Pendahuluan}

Subjective well being erat kaitannya dengan tumbuh kembang anak, bahkan hingga usia dewasa subjective well being akan mempengaruhi hidup seseorang. Subjective well being sendiri memiliki berbagai macam makna dari sudut pandang yang berbeda dari para ahli dalam bidang keilmuan ini 
khususnya ilmu psikologi. Dari makna paling umum yang dapat kita kenali adalah kebahagiaan atau kesejahteraan.

Azizah (2013) mengungkapkan bahwa kebahagiaan atau kesejahteraan hidup seseorang akan berdampak pada kelangsungan hidupnya sehari-hari. Pada berbagai sisi kehidupan manusia kebahagiaan menjadi faktor yang penting dalam menunjang kelancaran sebuah pekerjaan seseorang. Sebuah makna kebahagiaan dari berbagai orang termasuk jenis kelamin, usia dan pekerjaan atau aktivitas sehari-hari tentu memiliki pandangan berbeda tentang apa yang dapat membuat mereka memiliki tingkat kebahagiaan yang mereka inginkan. Tentunya pada tingkatan usia tertentu memiliki keinginan yang berbeda untuk memenuhi kebahagiaan mereka masing-masing. Dalam pandangan ahli yang menuturkan makna dari sebuah kebahagiaan adalah bagaimana seseorang memiliki kepuasan terhadap suatu hal, emosi yang positif.

Pada penelitian ini akan berfokus pada usia remaja. Bagaimana usia remaja dapat memiliki tingkat kebahagiaan yang sesuai dengan karakteristik mereka. Masa remaja dikenal sebagai masa peralihan, masa penekanan identitas diri dan ingin mengenal lawan jenis dan masa tidak ingin di atur untuk hidup yang mereka inginkan. Hal ini tidak jarang menimbulkan permasalahan tersendiri bagi mereka sehingga kembali mempengaruhi subjective well being atau kebahagiaan mereka.

Melihat dari kesehariannya remaja biasa kita temui di berbagai sekolah baik negri maupun swasta, dengan karakteristik berbeda dan gaya hidup yang berbeda-beda pula. Di sekolah para remaja biasanya merasa lebih nyaman dan senang karena dapat bercengkrama dengan teman sebayanya yang sesuai dengan mereka. Namun hal tersebut tidak selalu membuat remaja merasa bahagia seutuhnya.

Berdasarkan hasil observasi (wawancara) pada siswa di sekolah negeri yaitu SMAN 5 kota Bengkulu dengan responden berinisial DH dan DL pada 9 september 2019 menyatakan bahwa pada siswa di sekolah cenderung banyak mengeluhkan tentang akademik mereka yang begitu banyak di tuntut hingga hampir satu hari penuh waktu dihabiskan di sekolah. Banyak yang mereka harus kuasai, tetapi banyak juga aturan yang mengikat mereka sehingga tidak dapat membuat mereka merasa bebas dalam sekolah yang tentunya bertolak belakang dengan karakteristik remaj yang ingin bebas dan tidak mau diatur. Sehingga menimbulkan ketidakbahagiaan pada siswa di sekolah.

Saat ini juga di sekolah mewajibkan para siswa mengikuti ekstrakurikuler sebagai salah satu syarat mutlak kenaikan kelas. Siswa merasa tidak nyaman dengan aturan tersebut karena tidak banyak dari mereka senang berkegiatan semacam ekstrakurikuler sehingga membuat mereka hanya ikut-ikutan saja dan merasa hampa saat mengikuti kegiatan tersebut. Seperti yang diungkapkan oleh Seligman (2005: 10) yaitu jika emosi positif yang terpisah dari penggunaan karakter akan mengarah pada kepalsuan, kehampaan, depresi dan sejalan dengan semakin menuanya manusia, ada kesadaran yang mengusik hati yaitu berupa kegelisahan sepanjang hayat manusia.

Siswa di sekolah terkadang mengalami kehampaan yang berarti ketika mereka dituntut mengikuti kegiatan ekstra, belajar dengan banyak mata 
pelajaran yang harus dikuasai dan juga diikat dengan aturan yang bertolak dengan mereka sehingga menimbulkan perasaan tidak bahagia ketika sekolah seperti itu saja.Seperti dikemukakan ahli berikut bahwa ketidakbahagiaan dapat menimbulkan hancurnya penyesuaian diri baik secara sosial maupun pribadi (Hurlock, 1997:19).

Individu yang kurang bahagia memiliki penilaian yang negatif mengenai diri maupun kepada orang yang ada di sekitarnya. Oleh sebab itu individu yang kurang bahagia memiliki penyesuaian diri yang kurang baik.

Apabila hal tersebut terus terjadi, maka individu dapat mengalami kegagalan tugas perkembangan, khususnya pada aspek pribadi dan sosialnya. Dalam penelitian yang dilakukan, hal-hal yang ingin diungkap adalah mengetahui gambaran tentang deskripsi subjective well-being di sekolah swasta dan negeri serta mengetahui perbedaan antara keduanya.

Berdasarkan poin-poin permasalahan yang telah diuraikan di atas kemudian peneliti ingin mengetahui tingkat kebahagiaan siswa di sekolah yang bertujuan agar mencapai perkembangan yang sesuai. Untuk itu peneliti mengajukan judul "studi deskriptif tingkat subjective well being siswa SMA dan Swasta di Kota Bengkulu".

\section{Metode Peneleitian}

Desain penelitian yang digunakan peneliti adalah desain penelitian kuantitatif dengan metode deskriptif dan komparatif. Pada penelitian ini,yang menjadi populasi penelitian adalah siswa sekolah SMA negeri dan swasta di kota Bengkulu yang di pilih secara acak. Sampel pada penelitian ini terdiri siswa di SMA negeri dan swasta di kota Bengkulu. Besar sampel dalam penelitian ini diukur dengan menggunakan rumus Issac dan Michael, untuk mengetahui besaran sampel yang dibutuhkan agar dapat mewakili jumlah populasi yang ada. Rumusan besaran Issac dan Michael (Eriyanto, 2011:167).

Adapun prosedur pengambilan subjek penelitian ialah dengan menggunakan stratified random sampling dengan karakteristik simple cluster sampling. Pada stratified cluster sampling, populasi dikelompokkan kedalam strata yang homogen didalamnya sehingga kelompok itu akan heterogen dengan kelompok lainnya dan proses selanjutnya yaitu pemilihan cluster dari tiap stratum. Sampel penelitian ini yaitu, SMA Negeri 5 (160 sampel penelitian), SMA Negeri 10 (154 sampel penelitian), SMA Muhamadiyah (133 sampel penelitian), dan SMA It iqra (152 sampel penelitian.

Teknik pengumpulan data dalam penelitian ini menggunakan kuesioner. Sugiyono (2013:142) menyatakan bahwa kuesioner adalah sebuah teknik pengumpulan data yang dilakukan dengan memberikan seperangkat pertanyaan atau pernyataan tertulis kepada responden untuk dijawab. Angket yang digunakan adalah model Likert. Jawaban dari setiap item instrumen yang menggunakan skala Likert mempunyai gradasi dari sangat positif sampe sangat negatif (dalam Sarjono dan Julianita, 2013: 6). Dalam penelitian kali ini, peneliti akan memberikan kuesioner secara online dengan menggunakan aplikasi Google Form, yakni sebuah aplikasi survey online yang terdapat di Google.

Uji validitas pada penelitian ini menggunakan bantuan software SPSS versi 16 for windows. Berdasarkan hasil uji validitas kuesioner diperoleh hasil 
bahwa kuesioner subjective well being yang disebarkan ke 40 responden yang terdiri dari 56 item pernyataan didapatkan 4 item yang dinyatakan gugur dan 52 item yang dinyatakan valid. Peneliti menggunakan reliability analysis scale (Cronbach's alpha) karena rumus Cronbach's alpha lebih cocok digunakan pada kuesioner dengan skor jawaban dalam bentuk gradasi, seperti skala Likert yang menggunakan skor 1,2,3,4. Alpha Cronbach sebesar 0,974 yang berarti memiliki Alpha Cronbach $>0,8$ maka data subjective well being memiliki reliabilitas baik.

\section{Hasil dan Pembahasan}

Berdasarkan skor yang diperoleh, didapatkan gambaran umum skor subjective well being yang dihitung berdasarkan skor ideal. Gambaran umum tersebut dapat dilihat pada Tabel 1

\section{Tabel 1}

Deskripsi Subjective Well Being SMA Negeri di Kota Bengkulu

\begin{tabular}{lccccc}
\hline Sekolah & \multicolumn{3}{c}{ Kategori Subjective Well Being } & \\
& $\begin{array}{c}\text { Sangat } \\
\text { Rendah }\end{array}$ & Rendah & Tinggi & $\begin{array}{c}\text { Sangat } \\
\text { Tinggi }\end{array}$ & Total \\
\hline SMA IT & 1 & 119 & 31 & 1 & 152 \\
\cline { 2 - 5 } IQRA & $.2 \%$ & $19.9 \%$ & $5.2 \%$ & $.2 \%$ & $25.4 \%$ \\
\hline MU 4 & 6 & 89 & 38 & 0 & 133 \\
\cline { 2 - 5 } & $1.0 \%$ & $14.9 \%$ & $6.3 \%$ & $.0 \%$ & $22.2 \%$ \\
\hline SMAN5 & 0 & 25 & 126 & 9 & 160 \\
\cline { 2 - 5 } & $.0 \%$ & $4.2 \%$ & $21.0 \%$ & $1.5 \%$ & $26.7 \%$ \\
\hline SMAN10 & 1 & 26 & 126 & 1 & 154 \\
\cline { 2 - 5 } & $.2 \%$ & $4.3 \%$ & $21.0 \%$ & $.2 \%$ & $25.7 \%$ \\
\hline Total & 8 & 259 & 321 & 11 & 599 \\
& $1.3 \%$ & $43.2 \%$ & $53.6 \%$ & $1.8 \%$ & $100.0 \%$ \\
\hline
\end{tabular}

Berdasarkan tabel 1, diperoleh gambaran tentang subjective well being SMA negeri dan swasta di kota Bengkulu dengan persentase terdapat pada kategori tinggi untuk SMA Negeri sebanyak 321 siswa dengan persentase 53,6 $\%$ dan 259 siswa kategori rendah untuk SMA Swasta dengan persentase 43,2 $\%$.

\section{Tabel 2}

\section{Deskripsi Subjective Well Being SMA Swasta Kota Bengkulu}




\begin{tabular}{lccccc}
\hline \multicolumn{5}{c}{ Kategori Subjective Well Being } & \\
\hline & $\begin{array}{c}\text { Sangat } \\
\text { Rendah }\end{array}$ & Rendah & Tinggi & $\begin{array}{c}\text { Sangat } \\
\text { Tinggi }\end{array}$ & Total \\
\hline NEGER & 1 & 51 & 252 & 10 & 314 \\
\cline { 2 - 5 } I & $.2 \%$ & $8.5 \%$ & $42.1 \%$ & $1.7 \%$ & $52.4 \%$ \\
\hline \multirow{2}{*}{ SWAST } & 7 & 208 & 69 & 1 & 285 \\
\cline { 2 - 5 } A & $1.2 \%$ & $34.7 \%$ & $11.5 \%$ & $.2 \%$ & $47.6 \%$ \\
\hline & 8 & 259 & 321 & 11 & 599 \\
\cline { 2 - 5 } & $1.3 \%$ & $43.2 \%$ & $53.6 \%$ & $1.8 \%$ & $100.0 \%$ \\
\hline
\end{tabular}

Berdasarkan tabel 2 diperoleh gambaran tentang subjective well-being berdasarkan status sekolah. Pada sekolah negeri dengan persentase $42,1 \%$ sebanyak 252 siswa pada kategori tinggi. pada sekolah swasta sebanyak 208 siswa dengan persentse 34,7\% dengan kategori rendah.

Kuesioner subjective well being yang terdiri atas 51 item dengan 5 pilihan jawaban yang bergerak dari 1 sampai 5 sehingga diperoleh rentang minimum adalah $51 \times 1=51$ maximum adalah $51 \times 5=255$, sehingga luas jarak sebarannya adalah 255-51=204. Dengan demikian setiap satuan deviasi standarnya bernilai $\boldsymbol{\sigma}=204 / 6=34$ dan mean idealnya adalah 153. Berdasarkan perhitungan tersebut dapat dibuat kategorisasi data subjective well being sebagaimana pada Tabel 3

Tabel 3

Hasil Uji Perbedaan Subjective Well Being

\begin{tabular}{ccccc}
\hline NO & Sekolah & T & Sig T tailed & Ket \\
\hline 1 & Sman 5-Sma & $\begin{array}{c}-14.662,- \\
14.696\end{array}$ & $0.00-0.00$ & Signifikan \\
\hline 2 & Sman 5-MU4 & $\begin{array}{c}-13.681,- \\
13.766\end{array}$ & $0.00-0.00$ & Signifikan \\
\hline 3 & $\begin{array}{c}\text { Sman 5 - Sman } \\
10\end{array}$ & $\begin{array}{c}-1.679,-1.678 \\
\text { IT }\end{array}$ & $0.94-0.94$ & $\begin{array}{c}\text { Tidak } \\
\text { Signifikan }\end{array}$ \\
\hline 4 & $\begin{array}{c}\text { Sman 10 - Sma } \\
\text { IT }\end{array}$ & $\begin{array}{c}-12.594,- \\
12.591\end{array}$ & $0.00-0.00$ & Signifikan \\
\hline 5 & Sman 10-MU4 & $\begin{array}{c}-11.708,- \\
11.698\end{array}$ & $0.00-0.00$ & Signifikan \\
\hline 6 & Sma IT - MU4 & $-603,-604$ & $547-546$ & $\begin{array}{c}\text { Tidak } \\
\text { Signifikan }\end{array}$ \\
\hline
\end{tabular}

Berdasarkan table 3, dapat dilihat bahwa hasil uji $\mathrm{T}$ menunjukkan bahwa antara sekolah negeri dan swasta terdapat perbedaan yang signifikan dilihat dari besaran Sig $T$ tailed sebesar 0.00 yang artinya perbedaan signifikan. Sebaliknya tidak signifikan antara sekolah swasta dan swasta serta sekolah negeri dan sekolah negeri. Dilihat dari besaran Sig T tailed 547 - 546 dan $0.94-0.94$ yang artinya tidak signifikan.

Berdasarkan tabel diatas dapat dilihat bahwa berdasarkan hasil uji T, nilai sig (2-tailed) sebesar 0,000. Yang artinya lebih kecil dari 0,05. Sehingga kesimpulan yang di dapatkan adalah nilai signifikansi lebih besar dari 0,05 
yang artinya terdapat perbedaan tingkat Subjective Well Being yang signifikan antara SMA Negeri 5 dan SMA Muhammadiyah 4 di Kota Bengkulu.

Berdasarkan tabel diatas dapat dilihat bahwa berdasarkan hasil uji $\mathrm{T}$, nilai sig (2-tailed) sebesar 0,000. Yang artinya lebih kecil dari 0,05. Sehingga kesimpulan yang di dapatkan adalah nilai signifikansi lebih besar dari 0,05 yang artinya terdapat perbedaan tingkat Subjective Well Being yang signifikan antara SMA Negeri 10 dan SMA IT IQRA di Kota Bengkulu.

Tujuan penelitian ini ialah menjawab pernyataan tentang tingkat subjective well being siswa SMA Negeri dan Swasta di Kota Bengkulu. Penelitian ini menggunakan metode, artinya mendiskripsikan dan membandingkan hasil yang didapat. Proses yang telah di lakukan sebelumnya adalah menyebar angket. Pada stratified cluster sampling, populasi dikelompokkan kedalam strata yang homogen didalamnya sehingga kelompok itu akan heterogen dengan kelompok lainnya dan proses selanjutnya yaitu pemilihan cluster dari tiap stratum. Sampel penelitian ini yaitu. SMA Negeri 5 (160 sampel penelitian), SMA Negeri 10 (154 sampel penelitian).

SMA Muhamadiyah (133 sampel penelitian), dan SMA It iqra (152 sampel penelitian. Selanjutnya hasil kategorisasi data diperoleh hasil bahwa tingkat subjective well being siswa SMA Negeri dan Swasta di Kota Bengkulu menunjukkan bahwa seseorang yang memiliki subjective well being rendah maka cenderung kurang baik, dan seseorang yang memiliki subjective well being tinggi menunjukkan subjective well being tinggi. Hasil penelitian ini sesuai kategorisasi yaitu:

Dilihat dari hasil uji T pada tabel 4.8 dapat dilihat perbandingan tingkat Subjective Well Being antara SMA Negeri dan SMA swasta. Berdasarkan hasil uji T pada SMA Negeri 5 dan SMA Muhammadiyah 4 menunjukkan nilai sig(2-tailed) sebesar 0,000. Hal ini menunjukkan bahwa antara SMA Negeri 5 dan SMA Muhammadiyah 4 terdapat perbedaan yang signifikan dalam segi Subejctive Well Being. Hasil ini sesuai dengan kriteria apabila nilai $(p<0,05)$ maka terdapat perbedaan yang signifikan, begitu pula sebaliknya.

Pada tabel menunjukkan hasil uji T dari SMA Negeri 10 dan SMA IT IQRA. Berdasarkan hasil uji T menggunakan bantuan SPPS menunjukkan nilai Sig(2-tailed) sebesar 0,000. Hasil ini menunjukkan signifikansi $0,000<0,05(\mathrm{p}<0,05)$ yang artinya apabila nilai $\mathrm{p}$ lebih kecil dari 0,05 maka terdapat perbedaan yang signifikan antara SMA Negeri 10 dan SMA IT IQRA dalam segi Subjective Well Being.

Berdasarkan hasil uji T yang berguna untuk melihat perbedaan tingkat Subjective Well Being pada SMA Negeri dan SMA swasta yaitu SMA Negeri 5, SMA Negeri 10, SMA Muhammadiyah 4 dan SMA IT IQRA, secara menyeluruh dapat ditarik kesimpulan yaitu terdapat perbedaan yang signifikan tingkat Subjetive Well Being yang ada di SMA Negeri dan SMA swasta di Kota Bengkulu.

Subjective well being adalah analisis ilmiah tentang bagaimana individu melakukan evaluasi terhadap kehidupannya, termasuk sejumlah kenangan yang telah lama berlalu. Evaluasi-evaluasi ini melibatkan reaksi emosional individu terhadap sejumlah peristiwa kehidupan, suasana hati, 
serta penilaian mereka terhadap kepuasan hidup, kebermaknaan, dan kepuasan pada domain spesifik dari kehidupan seperti pernikahan dan pekerjaan. Kemudian, penelitian-penelitian tentang subjective well being terfokus pada apa yang disebut 'kebahagiaan' atau 'kepuasan' (Diener, Oishi, \& Lucas, 2003:195).

Subjective well being menurut Compton (2005:195), akan melibatkan dua variabel utama, yaitu kebahagiaan (happiness) dan kepuasan hidup (satisfaction with life). Kebahagiaan akan terkait dengan bagaimana keadaan emosi individual dan bagaimana mereka merasakan kehidupannya. Kepuasan hidup akan mengarah pada penilaian yang lebih luas tentang penerimaan masing-masing orang terhadap kehidupannya. Pendapat diatas adalah proses kognitif, dimana individu melakukan penilaian tentang kehidupan yang dialaminya, dan seberapa puas mereka dengan hidupnya. Faktor ketiga adalah neuroticism yang rendah (low neuroticism).

Perspektif ini didasarkan pada pengukuran dengan melihat karakter kepribadian seseorang, sikap-sikap, atau bagaimana cara individu memaknai pengalaman pengalaman hidupnya (Compton, 2005:120). Diener (2000) mengenalkan teori evaluasi, dimana kesejahteraan subjektif ditentukan oleh bagaimana cara individu mengevaluasi informasi atau kejadian yang dialami. Hal ini melibatkan proses kognitif yang aktif karena menentukan bagaimana informasi tersebut akan diatur. Cara-cara yang digunakan untuk mengevaluasi suatu peristiwa, juga dipengaruhi oleh temperamen, standar yang ditetapkan oleh individu, mood saat itu, situasi yang terjadi dan dialami saat itu serta pengaruh budaya.

Subjective well being yang harus dimiliki siswa menjadi tugas guru pembimbing untuk meningkatkannya. Hal itu guru pembimbing adalah guru yang mempunyai tugas, tanggung jawab, wewenang, dan hak secara penuh dalam kegiatan Bimbingan dan Konseling terhadap sejumlah peserta didik, termasuk dalam memberikan layanan BK kepada semua peserta didik di sekolah tempat dia bertugas dalam rangka mengantarkan peserta didik mencapai pertumbuhan dan perkembangan secara optimal (Umami, 2015: 45). Berdasarkan hasil penelitian yang telah dilakukan tersebut dapat disimpulkan SMA Negeri 5 Kota Bengkulu dan SMA Negeri 10 kota Bengkulu tergolong dalam kategori

tinggi, sedangkan SMA Muhamadiyah 4 kota Bengkulu dan SMA IT Iqra tergoling dalam kategori sedang. Adanya variasi kategori subjective well being siswa SMA negeri dan SMA swasta pada siswa dipengaruhi oleh sikap siswa yang juga bervariasi.

\section{Kesimpulan}

Berdasarkan hasil penelitian yang telah dilakukan, maka dikemukakanlah kesimpulan sebagai berikut: Tingkat subjective well-being siswa SMA Negeri dan swasta di Kota Bengkulu tergolong tinggi. Berdasarkan hasil analisis, terdapat perbedaan tingkat Subsjective Well Being antara sekolah negeri dan sekolah swasta namun secara menyeluruh tingkat Subjective Well Being siswa di SMA Negeri maupun Swasta tinggi dan rendah.

Dengan adanya penelitian ini, diharapkan setiap sekolah adapat menerapkan sistem pendidikan yang menjadikan siswanya enjoy dalam belajar sehingga dapat meningkatkan prestasi belajar setiap siswa. Sehingga, 
siswa dapat mengontrol reaksi individu terhadap kejadian-kejadian dalam hidup yang meliputi emosi yang menyenangkan dan emosi yang tidak menyenangkan

\section{Daftar Pustaka}

Azizah.(2013). Kebahagiaan dan Permasalahan di Usia Remaja. Jurnal Bimbingan Konseling Islam. Vol. 4, No. 2. 2013. Hal 115-124

Diener ed. (2000). Subjective well-being: the science of happiness and a proposal for a national index. American Psychologist Journal, 55(1), 3443.

Diener, E., \& Oishi, S. 2008. Recent Findings in Subjective well-Being. Indian Journal of clinical psychology. 24(1).25-41.

Diener, E., Tay, L., \& Oishi, S. (2013). Rising income and the subjective wellbeing of nations.Journal of personality and social psychology, 104(2),267-276.

Dini Baiq M, Yuniawati R. (2015). Perbedaan Adaptabilitas Karir Ditinjau Dari Jenis Sekolah (Sma Dan Smk). Jurnal Fakultas Psikologi Vol. 3, No 1, Juli 2015 Hal:1-11

Fithriwati Dian, D,. Himam Fathul. (2015). Subjective Well Being pada Hakim yang Bertugas di Daerah Terpencil. Gadjah Mada Journal Of Psychology. Volume 1, No. 3. 2015. Hal $192-203$

Hamdana Fara, dan Alhamdu.(2015). Subjective Well-Being Dan Prestasi Belajar Siswa Akselerasi Man 3 Palembang. Jurnal Psikologi islami. Volume 1, No 2. 2015. Hal 115-124

Hamka. (2017). Sekolah Negeri Dan Sekolah Swasta:Monopoli Dalam Pendidikan. Jurnal el-Idare, Vol. 1, No. 2, Desember 2017. Hal : 217 $-230$

Sekaran, Umar (2000). Metode Penelitian. Edisi Keempat. Jakarta: Salemba Empat.

Sugiyono. (2010). Metode Penelitian Kuantitatif Kualitatif dan Research and Development. Bandung: Alfabeta.

Yusuf. (2010). Metode penelitian pendidikan dan sosial. Bandung: Alfabeta 